\title{
COMPARATIVE ANALYSIS OF DIRECT AND FOUR INDIRECT METHODS FOR DETERMINATION OF EVAPOTRANSPIRATION OF WATERLEAF (TALINUM TRIANGULARE)
}

\author{
C.P. Obioma ${ }^{1}$, C.D. Okereke ${ }^{2}$, K.N. Nwaigwe ${ }^{3}$ \\ ${ }^{1}$ PG student, Agricultural Engineering, Federal University of Technology, Owerri, Imo State, Nigeria \\ ${ }^{2}$ Professor of Environmental Engineering, Federal University of Technology, Owerri, Imo State, Nigeria \\ ${ }^{3}$ Senior lecturer, Agricultural Engineering Department, Federal University of Technology, Owerri, Imo State, Nigeria
}

\begin{abstract}
This study focused on comparative analysis of five widely used methods for determining evapotranspiration, namely, Weighing lysimeter, Pan Evapotranspiration, Blaney - Morin Nigeria, Blaney - Criddle and Modified Hargreaves - Samani methods. Each of the five methods was used to estimate crop evapotranspiration of waterleaf (Talinum triangulare) in Umudike, Southeast Nigeria. The efficacy of these evapotranspiration methods is evaluated by comparing them with the Weighing lysimeter(direct method), which provides the most reasonable estimation of evapotranspiration and is one of the most reliable methods. The crop was irrigated daily and the daily data generated from the lysimeter were used to calculate the crop evapotranspiration (ETc) between the months of November/ December, 2013. Climatic data obtained for the same period were used to determine the crop evapotranspiration (ETC) using the Pan Evapotranspiration, Blaney - Morin Nigeria, Blaney - Criddle and Modified Hargreaves - Samani methods. The total crop evapotranspiration from the Lysimeter between November and December was 148.69 mm, while that of Pan Evapotranspiration (PE), Blaney - Morin Nigeria (BMN), Blaney - Criddle (BC) and Modified Hargreaves Samani (MHS) were $152.42 \mathrm{~mm}, 151.22 \mathrm{~mm}, 147.76 \mathrm{~mm}$ and $135.58 \mathrm{~mm}$, respectively. Test of hypothesis using z-Test indicates that there was no significant difference between the mean of the ET by lysimeter and that of each of the other four methods (Blaney - Criddle, Pan Evapotranspiration, Modified Hargreaves - Samani and Blaney - Morin Nigeria) as z-cal < z-critical at $5 \%$ level of significance for the crop growth period of $8^{\text {th }}$ November to $12^{\text {th }}$ December, 2013.
\end{abstract}

Keywords: Comparative analysis, Evapotranspiration methods, Crop evapotranspiration, Hydrologic cycle, Lysimeter ****

\section{INTRODUCTION}

Evapotranspiration is defined as the combination of two distinct processes: the evaporation of the water directly from the ground surface and the transpiration through the plants' stomata [3]. Accurate evapotranspiration estimates are essential to identify the time variations on irrigation needs, to improve the allocation of water resources, and to evaluate the effect of the use of the land and changes in the management of the water balance [17]. Evapotranspiration can be obtained by direct or estimate measures of climatic elements, using empirical methods. The direct method is represented by several types of lysimeters, being the most accurate method, and considered standard - tool for the determination of evapotranspiration $[4,6]$. There are several empirical methods in literature that use meteorological elements data to estimate the evapotranspiration. These methods are based on observations and statistical analysis, and are generally adequate for a specific climatic or region condition [1, 12, 13]. Amongst the empirical methods, the Penman - Monteith - FAO 56 method is considered standard to estimate the ET because it compasses the physical parameters that govern the exchange of energy, aerodynamic and physiological aspects of the culture [2, 20].
Evaporimeters such as the Class A Pan is one of the simplest empirical methods to estimate ET, for irrigation water management purposes. According to Sediyama [19], the greater use of this equipment is due to its convenience and low installation and maintenance cost. In accordance with Smith [20], when well used, this method offers trustworthy results in the determination of ET. It has the advantage of measuring the evaporation of water - free surface, associating the integrated effects of solar radiation, wind, temperature and humidity of air.

Hargreaves and Samani [14] developed a simplified equation requiring only temperature and latitude for calculating reference evapotranspiration, $\mathrm{ET}_{\mathrm{o}}$. This method has produced good results, because at least 80 percent of $\mathrm{ET}_{\mathrm{o}}$ can be explained by temperature and solar radiation [13]. The ability of the method to account both for temperature and radiation provides it with great resilience in diverse climates around the world.

Duru [10] proposed a Nigeria model based on the original equation of Blaney and Morin [8]. The Blaney - Morin Nigeria (BMN) evapotranspiration model was developed for application in Nigeria. 
Blaney and Criddle [7] developed a model which was used in the determination of crop evapotranspiration. They calculated evapotranspiration from mean monthly temperature and percentage of total annual daylight hours occurring during the period being considered [9].

Hydrologists and other water resources management experts have observed that water covers three-quarter (3/4) of the earth's surface. However, inaccessibility, lack of appropriate technology to access fresh water for supply to demand points, climate change, high water demand for domestic, industrial and agricultural needs have led to water shortages being experienced mostly in developing countries. Most regions of the world engage in agriculture for production of food and raw materials for industries, Asia and Africa are the worst hit by water shortage despite the fact that most of their countries depend on agriculture for foreign exchange and food. The proper planning, use and management of limited water resources is a sure way to proffer solutions to water shortage, poor crop yields and food crisis. Lysimeters (method) provides the most reasonable estimation of ET and it is one of the most reliable methods which consider the atmospheric changes comprehensively $[3,16,18]$. Crop ET determination is required in irrigation water management.

The objectives of this study are to determine the evapotranspiration of waterleaf at National Root Crops Research Institute (NRCRI), Umudike, Southeast, Nigeria, using direct method (Weighing lysimeter) and four indirect methods (Modified Hargreaves-Samani, Blaney - Morin Nigeria , Blaney - Criddle and Pan evapotranspiration) and to make comparative analysis of the five methods used in the determination of evapotranspiration of waterleaf. This is with a view to establishing the adequacy of choice of the five methods to estimate ET in the study area.

\section{MATERIALS AND METHODS}

\subsection{Study Area}

National Root Crops Research Institute (NRCRI), Umudike is situated on longitude $07^{\circ} 33^{\prime} \mathrm{N}$ and latitude $05^{\circ} 29^{\prime} \mathrm{N}$. it is located in Ikwuano Local Government Area of Abia State, Nigeria. They occupy a total land of 600 hectares. It is in the humid tropical climatic region and is characterized by two distinct seasons (wet and dry seasons). The wet season occurs mainly between April and October while the dry season is experienced during the remaining months of the year (November to March). The area is endowed with sandy loam soil (Anon, 1973).

\subsection{Lysimeter Set-Up}

Three sets of lysimeter were assembled and used for this study. Each set of the lysimeter has a depth of $0.37 \mathrm{~m}$ and diameter of $0.31 \mathrm{~m}$. In order to prevent soil particles from causing blockade in the lysimeter through the drainage outlet, a fibre mesh size of $0.21 \mathrm{~mm}$ is placed at the bottom of the lysimeter to act as a filter mechanism and facilitator of drainage. Then the lysimeter was mounted on a platform and filled with the sandy loam soil of the environment of the study area. It was irrigated with a known volume of water. The lysimeter was connected at its base to a $2 \mathrm{~cm}$ diameter plastic pipe, of length of $0.98 \mathrm{~m}$ as drainage outlet. A 10 liter plastic container was used to collect drained water. Then the lysimeter system was allowed to stand and set for 24 hours after irrigation and drainage processes. Before transplanting the test crops, the lysimeter was allowed to stop draining water from the drainage outlet after saturation. The materials used in the study (plate 1) were a Weighing lysimeter which was the main experimental set up used in the determination of the crop evapotranspiration and an electronic weighing balance used for weighing the lysimeter before and after irrigation of waterleaf (Talinum triangulare) crop (plate 1 and 2).

\subsection{Data Collection}

The irrigation was carried out by measuring out a quantity of water in a calibrated container before application by watering can method. The lysimeter was drained by gravity and percolated water was collected in the collection container through a drain pipe and was measured with a measuring cylinder. For the computation of evapotranspiration using modified Hargreaves-Samani, Blaney - Morin Nigeria, Blaney - Criddle and Pan Evapotranspiration methods. The weather data collected from the Meteorological station at National Root Crops Research Institute, Umudike include air temperature, sunshine hours, relative humidity, and solar radiation. 


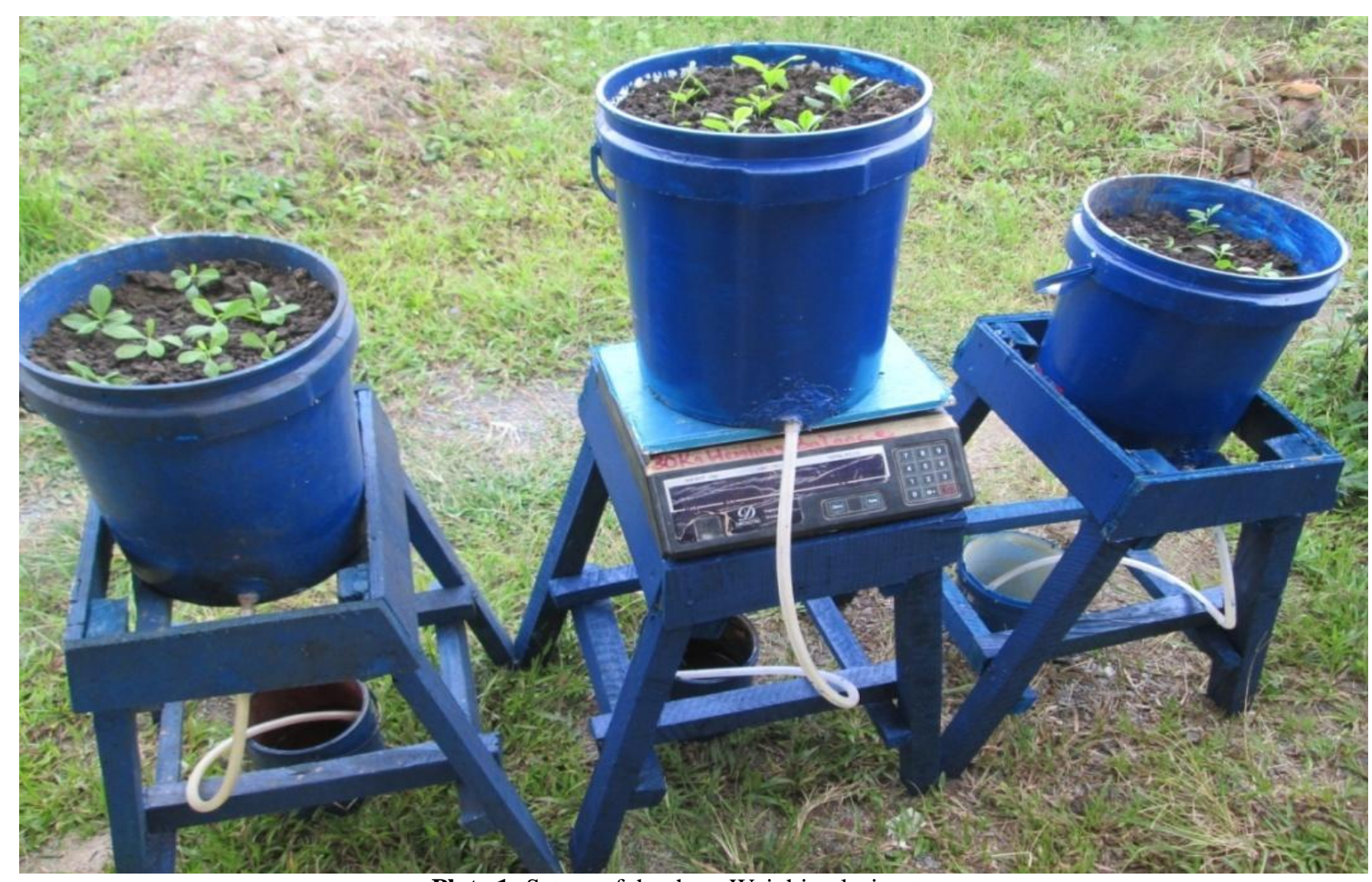

Plate 1: Set-up of the three Weighing lysimeters

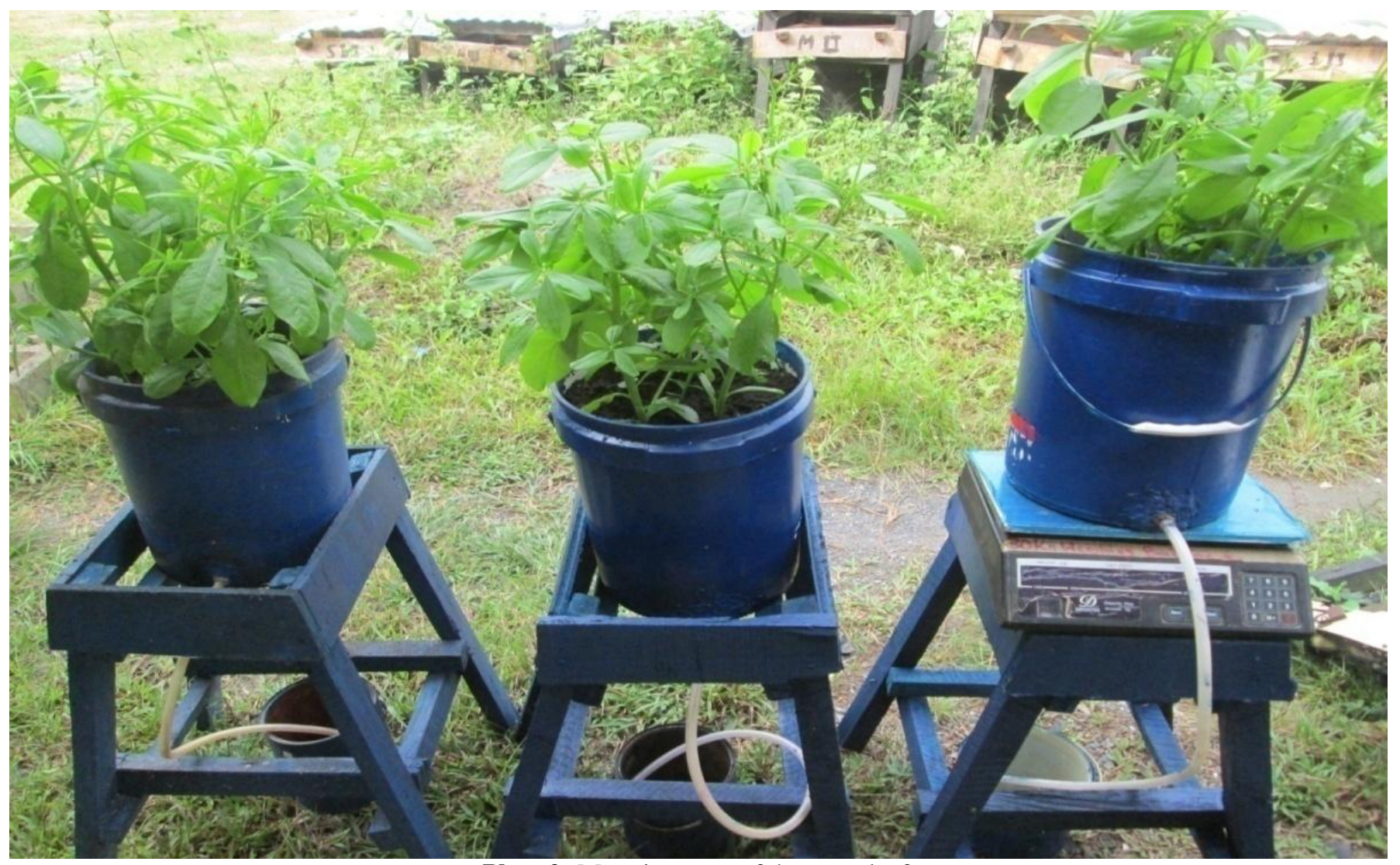

Plate 2: Maturity stage of the waterleaf 


\subsection{Determination of Evapotranspiration (ET)}

\section{The Modified Hargreaves-Samani (MHS) method}

The form of Hargreaves-Samani equation presented in FAO - 56 by Allen et al., [2] is:

$$
\mathrm{ET}_{\mathrm{o}}=0.0023 \times\left(\mathrm{T}_{\max }-\mathrm{T}_{\text {min }}\right)^{0.5}\left(\mathrm{~T}_{\text {mean }}+17.8\right) \mathrm{R}_{\mathrm{a}} \quad \ldots . . \text { eqn. } 1
$$

Where $\mathrm{ET}_{\mathrm{o}}$ is reference evapotranspiration $\left(\mathrm{mm} \mathrm{day}^{-1}\right)$

$\mathrm{T}_{\text {mean }}$ is the daily mean air temperature $\left({ }^{\circ} \mathrm{C}\right)$

$\mathrm{T}_{\max }$ is the daily maximum air temperature $\left({ }^{\circ} \mathrm{C}\right)$

$\mathrm{T}_{\text {min }}$ is the daily minimum air temperature $\left({ }^{\circ} \mathrm{C}\right)$

$\mathrm{R}_{\mathrm{a}}$ is the extraterrestrial radiation $\left(\mathrm{mm}\right.$ day $^{-1}$ )

The crop coefficient of waterleaf for development and final stage is 1 and 0.95 respectively [11].

\section{Blaney - Morin Nigeria (BMN) model}

The evapotranspiration is computed using the formulas developed by Blaney - Morin Nigeria [10].

$$
\mathrm{ET}=\frac{r_{f}(0.45 t+8)\left(520-R^{1.31}\right)}{100}
$$

Where, ET = evapotranspiration $(\mathrm{mm} /$ day $)$

$r_{\mathrm{f}}=$ radiation ratio $/$ fraction $=r_{\text {daily }} / r_{\max }$

$\mathrm{r}_{\text {daily }}=$ daily radiation

$r_{\max }=$ maximum monthly radiation,

$\mathrm{T}=$ temperature $\left({ }^{\circ} \mathrm{C}\right), \mathrm{R}=$ daily relative humidity $(\%)$

Blaney - Criddle (BC) method

The evapotranspiration is calculated by the equation developed by Blaney and Criddle [7].

$$
\mathrm{ET}_{\mathrm{o}}=\mathrm{p}\left(0.46 \mathrm{~T}_{\text {mean }}+8\right) \quad \text {.... eqn. } 3
$$

Where, $\mathrm{ET}_{\mathrm{o}}=$ reference crop evapotranspiration $\quad(\mathrm{mm} /$ day $)$

$\mathrm{T}_{\text {mean }}=$ mean daily temperature $\left({ }^{\circ} \mathrm{C}\right)$

$\mathrm{P}=$ mean daily percentage of monthly day time hours

\section{The Pan Evapotranspiration (PE) Method}

The reference evapotranspiration will also be determined by pan evaporation method using Class A pan. The relationship between the evaporation and the reference evapotranspiration is given as;

$$
\mathrm{ET}_{\mathrm{o}}=\mathrm{K}_{\mathrm{p}} \times \mathrm{E}_{\mathrm{p}} \quad \ldots . \quad \text { eqn. } 4
$$

Where $\mathrm{ET}_{\mathrm{o}}=$ Reference evapotranspiration $\mathrm{K}_{\mathrm{p}}=$ Pan coefficient, $\mathrm{E}_{\mathrm{p}}=$ Pan evaporation

The crop evapotranspiration $\left(\mathrm{ET}_{\mathrm{c}}\right)$ is calculated using the equation

$$
\mathrm{ET}_{\mathrm{c}}=\mathrm{ET}_{\mathrm{o}} \times \mathrm{K}_{\mathrm{c}} \quad \text {.... eqn. } 5
$$

Where $\mathrm{ET}_{\mathrm{c}}=$ Crop evapotranspiration, $\mathrm{ET}_{\mathrm{o}}=$ Reference evapotranspiration

$\mathrm{K}_{\mathrm{c}}=$ Crop coefficient.

The daily evaporation values were multiplied with the pan coefficient $(0.8)$ to get the reference evapotranspiration which was further multiplied with the crop coefficient to get the crop evapotranspiration. For waterleaf, crop coefficient for the development stage or mid stage is 1 , while the late season is 0.95 [11].

\subsection{Data analysis}

The ET data of the five methods was subjected to z-Test in Excel computer software to determine if there is significant difference between the means of the ET determined by Weighing Lysimeter and each of the other methods (Pan Evapotranspiration (PE), Blaney - Morin Nigeria (BMN), Blaney - Criddle (BC) and Modified Hargreaves - Samani (MHS).

The following hypothesis was tested:

The Null hypothesis, Ho: $\mu_{1}=\mu_{2}=\ldots \mu_{\mathrm{k}}$ where $\mu$ is the population means, that is, there is no significant difference between evapotranspiration of waterleaf determined by Weighing Lysimeter and each of the other four methods (BMN, BC, PE, MHS), where $\mathrm{K}$ is $1-5$.

The alternative hypothesis, $\mathrm{H} 1: \mu_{1} \neq \mu_{2}=\ldots \mu_{\mathrm{k}}$, that is, there is a significant difference in the evapotranspiration of waterleaf determined by Weighing Lysimeter and each of the other four methods (BMN, BC, PE, MHS).

\section{RESULTS AND DISCUSSION}

\subsection{Results}

Results of evapotranspiration estimated by the five methods are presented in Table 1.The results of statistical comparison of means of the crop ET by the Lysimeter method with that obtained by each of the other four methods at 5\% level of significance are presented in Table 2, Table 3, Table 4, Table 5. Figure 1 show the $\mathrm{ET}_{\mathrm{c}}$ trend after planting the crop (waterleaf) for the five different methods used to determine crop evapotranspiration. Figure 2 show the trend of crop ET of the five different methods with Relative humidity and Temperature variations. 


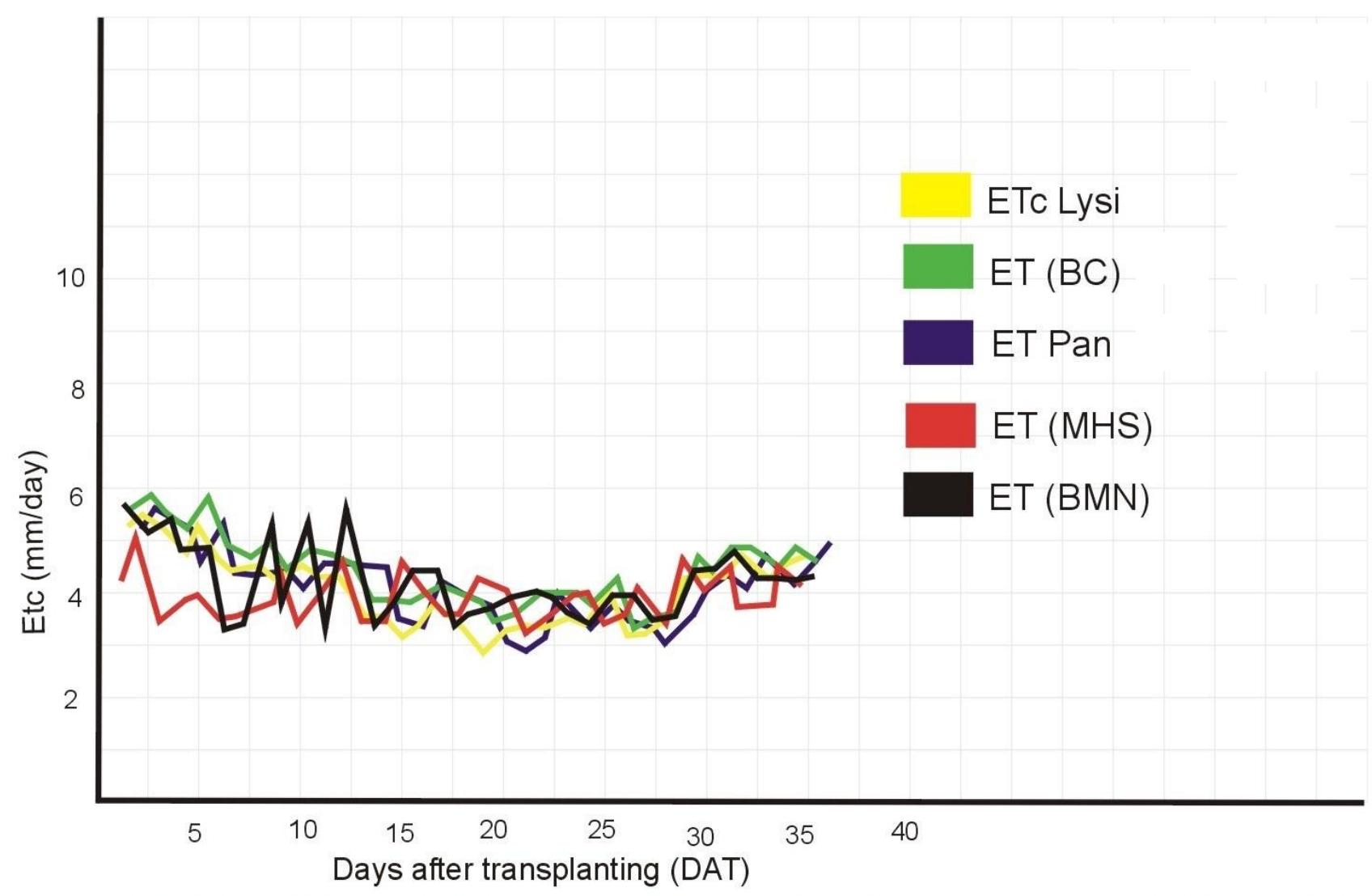

Figure 1: Trend of ETc of the five different methods for 8th November to 12th December period

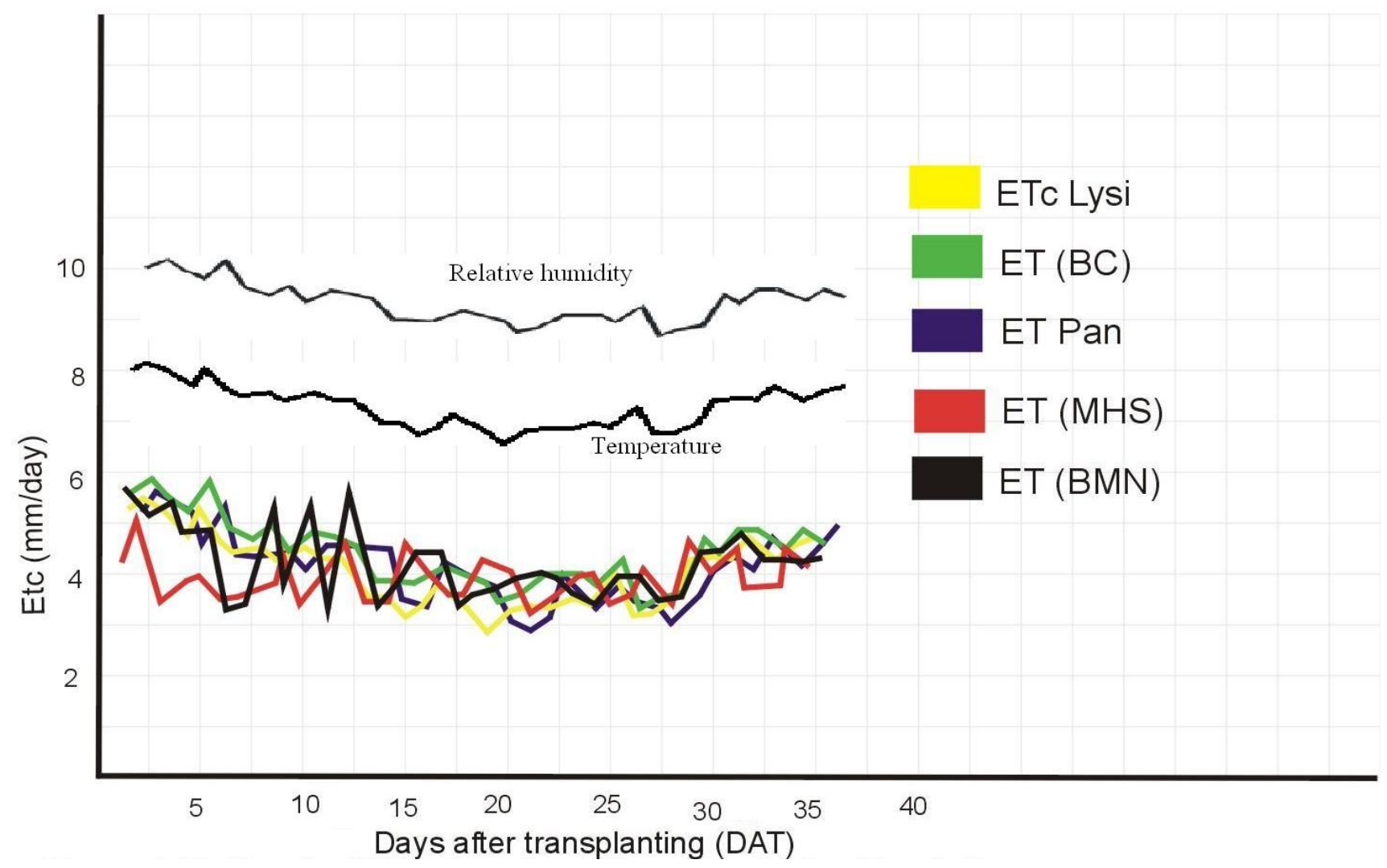

Fig 2: Trend of ETc of the five different methods with Relative humidity and Temperature variations 
Table 1: Comparison of results from the five methods $\left(8^{\text {th }}\right.$ November $-12^{\text {th }}$ December, 2013)

\begin{tabular}{|c|c|c|c|c|c|}
\hline Days & $\begin{array}{l}\text { ETc lysimeter } \\
\text { (mm/day) }\end{array}$ & $\begin{array}{l}\text { ETc Blaney- } \\
\text { Criddle } \\
\text { (mm/day) }\end{array}$ & $\begin{array}{l}\text { ETc Pan } \\
\text { evaporation } \\
\text { (mm/day) }\end{array}$ & $\begin{array}{l}\text { ETc Hargreaves } \\
\text { Samani } \\
(\mathrm{mm} / \text { day })\end{array}$ & $\begin{array}{l}\text { ETc Blaney- } \\
\begin{array}{l}\text { Morin Nigeria } \\
(\mathrm{mm} / \text { day })\end{array}\end{array}$ \\
\hline 1 & 5.37 & 5.46 & 5.44 & 4.24 & 5.76 \\
\hline 2 & 5.59 & 5.59 & 5.60 & 4.89 & 5.33 \\
\hline 3 & 5.34 & 5.30 & 5.36 & 4.25 & 5.67 \\
\hline 4 & 4.94 & 4.97 & 4.88 & 4.77 & 4.79 \\
\hline 5 & 5.53 & 5.46 & 5.44 & 3.80 & 4.99 \\
\hline 6 & 4.83 & 4.84 & 4.72 & 4.56 & 3.46 \\
\hline 7 & 4.55 & 4.54 & 4.64 & 4.58 & 3.40 \\
\hline 8 & 4.74 & 4.78 & 4.80 & 4.92 & 5.37 \\
\hline 9 & 4.44 & 4.41 & 4.48 & 4.23 & 3.88 \\
\hline 10 & 4.57 & 4.71 & 4.72 & 4.54 & 5.29 \\
\hline 11 & 4.51 & 4.64 & 4.56 & 3.48 & 3.39 \\
\hline 12 & 4.43 & 4.53 & 4.48 & 4.27 & 5.70 \\
\hline 13 & 3.61 & 3.64 & 4.56 & 4.44 & 3.18 \\
\hline 14 & 3.47 & 3.48 & 3.60 & 4.25 & 3.70 \\
\hline 15 & 3.32 & 3.38 & 3.52 & 4.39 & 4.48 \\
\hline 16 & 3.44 & 3.56 & 4.48 & 4.93 & 4.53 \\
\hline 17 & 3.90 & 3.87 & 4.32 & 4.70 & 3.30 \\
\hline 18 & 3.53 & 3.64 & 4.00 & 3.73 & 3.73 \\
\hline 19 & 3.12 & 3.33 & 3.28 & 4.32 & 3.81 \\
\hline 20 & 3.37 & 3.39 & 3.12 & 4.21 & 4.00 \\
\hline 21 & 3.74 & 3.74 & 3.44 & 4.32 & 4.10 \\
\hline 22 & 3.74 & 3.74 & 4.16 & 4.36 & 4.04 \\
\hline 23 & 3.81 & 3.94 & 3.52 & 3.90 & 3.87 \\
\hline 24 & 3.69 & 3.73 & 3.92 & 4.21 & 3.74 \\
\hline 25 & 4.24 & 3.97 & 3.88 & 3.23 & 3.98 \\
\hline 26 & 3.29 & 3.06 & 3.50 & 4.45 & 3.95 \\
\hline 27 & 3.34 & 3.16 & 3.42 & 4.07 & 3.62 \\
\hline 28 & 3.59 & 3.36 & 3.88 & 4.35 & 3.68 \\
\hline 29 & 4.53 & 4.41 & 4.26 & 3.61 & 4.67 \\
\hline 30 & 4.49 & 4.26 & 4.64 & 4.02 & 4.74 \\
\hline 31 & 4.53 & 4.45 & 4.41 & 4.43 & 4.81 \\
\hline 32 & 4.77 & 4.50 & 5.02 & 3.81 & 4.47 \\
\hline 33 & 4.57 & 4.31 & 4.34 & 4.87 & 4.56 \\
\hline 34 & 4.82 & 4.60 & 4.94 & 4.27 & 4.59 \\
\hline 35 & 4.94 & 4.71 & 5.09 & 4.24 & 4.64 \\
\hline Total & 148.69 & 147.46 & 152.42 & 149.64 & 151.22 \\
\hline Mean & 4.25 & 4.21 & 4.35 & 4.28 & 4.32 \\
\hline Standard deviation & 0.484 & 0.431 & 0.430 & 0.155 & 0.528 \\
\hline
\end{tabular}

Table 2: Summary of z-Test for comparing ETc Lysimeter and Blaney - Criddle (BC) methods for $8^{\text {th }}$ November $-12^{\text {th }}$ December period

\begin{tabular}{|l|l|l|}
\hline z-Test: & & \\
\hline & $E T_{C}$ LYSIMETER $(\mathrm{mm} /$ day $)$ & $E T_{C}$ BC $(\mathrm{mm} /$ day $)$ \\
\hline Mean & 4.248285714 & 4.213142857 \\
\hline Known Variance & 0.502638 & 0.488405 \\
\hline Observations & 35 & 35 \\
\hline $\begin{array}{l}\text { Level of significance } \\
\text { Hypothesized Mean Difference }\end{array}$ & 0 & \\
\hline $\mathrm{z}$-cal & 0.208845364 & \\
\hline $\mathrm{P}(\mathrm{Z} \leq \mathrm{z})$ two-tail & 0.834568956 & \\
\hline $\mathrm{z}$ Critical two-tail & 1.959963985 & \\
\hline
\end{tabular}

Inference: mean $\mathrm{ET}_{\mathrm{c}}$ of waterleaf by Lysimeter method $\left(\mu_{1}\right)$ is same as that obtained by Blaney - Criddle method $\left(\mu_{\mathrm{BC}}\right)$ that is, $\mu_{1}=$ $\mu_{\mathrm{BC}}$ 
Table 3: Summary of z-test for comparing ETc Lysimeter and Pan Evapotranspiration (PE) methods for $8^{\text {th }}$ November $-12^{\text {th }}$ December period

\begin{tabular}{|c|c|c|}
\hline \multicolumn{2}{|l|}{ z-Test: } & \\
\hline & $\begin{array}{l}\text { ET } T_{C} \text { LYSIMETER } \\
(\mathrm{mm} / \text { day })\end{array}$ & $\begin{array}{l}E T_{C} P E \\
(\mathrm{~mm} / \text { day })\end{array}$ \\
\hline Mean & 4.248285714 & 4.354857143 \\
\hline Known Variance & 0.502638 & 0.446426 \\
\hline Observations & 35 & 35 \\
\hline $\begin{array}{ll}\text { Level of significance } & 5 \% \\
\text { Hypothesized Mean Difference } & \end{array}$ & 0 & \\
\hline Z-cal & -0.647182939 & \\
\hline $\mathrm{P}(\mathrm{Z} \leq \mathrm{z})$ two-tail & 0.517513552 & \\
\hline z Critical two-tail & 1.959963985 & \\
\hline
\end{tabular}

Inference: mean $\mathrm{ET}_{\mathrm{c}}$ of waterleaf by Lysimeter method $\left(\mu_{1}\right)$ is same as that obtained by Pan Evapotranspiration method $\left(\mu_{\mathrm{PE}}\right)$ that is, $\mu_{1}=\mu_{\mathrm{PE}}$

Table 4: Summary of z-test for comparing ETc by Lysimeter and Modified Hargreaves - Samani (MHS) methods for $8^{\text {th }}$

\begin{tabular}{|l|l|l|}
\hline z-Test: & & \\
\hline & & $\begin{array}{l}\text { ETc MHS } \\
(\mathrm{mm} / \text { day })\end{array}$ \\
\hline & $\begin{array}{l}\text { ETc LYSIMETER } \\
(\mathrm{mm} / \text { day })\end{array}$ & 4.275428571 \\
\hline Mean & 4.248285714 & 0.162543 \\
\hline Known Variance & 0.502638 & 35 \\
\hline Observations & 35 & \\
\hline $\begin{array}{l}\text { Level of significance } \\
\text { Hypothesized Mean Difference }\end{array}$ & 0 & \\
\hline z-cal & -0.196888189 & \\
\hline P(Z $\leq$ z) two-tail & 0.843915036 & \\
\hline z Critical two-tail & 1.959963985 & \\
\hline
\end{tabular}

Inference: mean $\mathrm{ET}_{\mathrm{c}}$ of waterleaf by Lysimeter method $\left(\mu_{1}\right)$ is same as that obtained by Modified Hargreaves - Samani method $\left(\mu_{\mathrm{MHS}}\right)$ that is, $\mu_{1}=\mu_{\mathrm{MHS}}$

Table 5: Summary of z-test for comparing ETc by Lysimeter and Blaney - Morin Nigeria (BMN) methods for $8^{\text {th }}$ November -

\begin{tabular}{|c|c|c|}
\hline \multicolumn{2}{|l|}{ z-Test: } & \\
\hline & $\begin{array}{l}\text { ET } T_{C} \text { LYSIMETER } \\
(\mathrm{mm} / \text { day })\end{array}$ & $\begin{array}{l}E T_{C} B M N \\
(\mathrm{~mm} / \mathrm{day})\end{array}$ \\
\hline Mean & 4.248285714 & 4.320571429 \\
\hline Known Variance & 0.502638 & 0.538094 \\
\hline Observations & 35 & 35 \\
\hline $\begin{array}{ll}\text { Level of significance } & 5 \% \\
\text { Hypothesized Mean Difference } & \\
\end{array}$ & 0 & \\
\hline Z-cal & -0.419195918 & \\
\hline $\mathrm{P}(\mathrm{Z} \leq \mathrm{z})$ two-tail & 0.675072955 & \\
\hline z Critical two-tail & 1.959963985 & \\
\hline
\end{tabular}

Inference: mean $\mathrm{ET}_{\mathrm{c}}$ of waterleaf by Lysimeter method $\left(\mu_{1}\right)$ is same as that obtained by Blaney - Morin Nigeria method $\left(\mu_{\mathrm{BMN}}\right)$ that is, $\mu_{1}=\mu_{\mathrm{BMN}}$ 


\subsection{Discussion}

In Figure 1, the waterleaf evapotranspiration obtained by the different methods (Lysimeter, Blaney-Morin Nigeria, Blaney - Criddle, Pan Evapotranspiration and Modified Hargreaves - Samani) follow similar trend of slight increase at the early crop growth stage and gradually decreases at the mid - season stage and increases again at the late season stage of $8^{\text {th }}$ November to $12^{\text {th }}$ December, 2013. The reason for the trend in the crop evapotranspiration observed is due to the stage of crop growth and high temperature (Figure 2) causing increase in the evapotranspiration of the crop. In Table 1, the evapotranspiration of waterleaf determined by Lysimeter, Pan Evapotranspiration (PE), Blaney - Morin Nigeria (BMN), Blaney - Criddle (BC) and Modified Hargreaves - Samani (MHS) methods of $8^{\text {th }}$ November to $12^{\text {th }}$ December were of values of $148.69 \mathrm{~mm}, 152.42 \mathrm{~mm}$, $151.22 \mathrm{~mm}, 147.46 \mathrm{~mm}$ and $149.64 \mathrm{~mm}$, respectively. The variation of the crop evapotranspiration is related to environmental factors of temperature and relative humidity as shown in Figure 2. The variations of climatic factor affected the crop evapotranspiration measured resulting to the observed trend. The $\mathrm{z}$ - test for comparison of mean evapotranspiration result for the study period showed that statistically, there is no significant difference between the evapotranspiration of waterleaf determined by the direct method (lysimeter) and the other four methods, (Pan evapotranspiration (PE), Blaney - Morin Nigeria (BMN), Blaney - Criddle (BC) and Modified Hargreaves - Samani, MHS) at $5 \%$ level of significance as $\mathrm{z}-$ cal $<\mathrm{z}-$ critical (Tables 2, 3, 4 and 5). Since Lysimeter is the most widely accepted direct method, the Pan Evapotranspiration, Blaney - Morin Nigeria, Blaney - Criddle and Modified Hargreaves - Samani methods can be said to be suitable for the estimation of the crop evapotranspiration of waterleaf in Umudike, Southeast Nigeria. The efficiency of the five ET determination methods was tested in this study with the aim to guide the researchers and experts in the water resources sector in selecting appropriate methods for estimating ET of waterleaf in the study area. The measure of the adequacy and reliability of the other four ET methods ascertained by comparing ET estimates by each method with that of the of the Weighing Lysimeter showed that all the methods gave same ET mean value within $95 \%$ confidence level. Although the capability of these indirect methods are almost same, the Pan evapotranspiration method followed by Blaney Criddle method needs less number of parameters (eqns. 1 5) to estimate ET than Modified Hargreaves - Samani method and Blaney - Morin Nigeria method, and therefore easier to use and economical in terms of time cost function. The daily ET variation about the mean value approximates to sinusoidal pattern with respect to crop growth as the values kept rising and falling throughout the crop growing season. This is typical of daily ET during the growth seasons as higher ET does happen on very sunny day and cloudless days. The pattern of crop ET with respect to crop growth was best observed using the daily average ET of the crop.

\section{CONCLUSION}

The values of crop ET determined by Pan Evapotranspiration, Blaney - Morin Nigeria, Blaney Criddle and Modified Hargreaves - Samani methods were validated by the Weighing lysimeter method. The study revealed that the crop evapotranspiration of waterleaf (Talinum triangulare) in Umudike, Southeast Nigeria between the month of November and December 2013 from Weighing lysimeter, Pan Evapotranspiration, Blaney Morin Nigeria, Blaney - Criddle and Modified Hargreaves Samani methods were $148.69 \mathrm{~mm}, 152.42 \mathrm{~mm}, 151.22 \mathrm{~mm}$, $147.46 \mathrm{~mm}$ and $149.64 \mathrm{~mm}$, respectively.

The comparative analysis using statistical Z-test showed that there was no significant difference between the mean value of the ET determined by lysimeter and that of each of the other methods (Blaney - Criddle, Pan Evapotranspiration, Modified Hargreaves - Samani and Blaney - Morin Nigeria) at $5 \%$ level of significance for the growth period of $8^{\text {th }}$ November to $12^{\text {th }}$ December, 2013. From the analysis, it was concluded that any of the five methods for determining ET is suitable for estimating ET of waterleaf (Talinum triangulare) in the study area.

\section{REFERENCES}

[1]. Ahmadi, S.H. and Fooladmand, H.R. (2008). Spatially distributed monthly reference evapotranspiration derived from the calibration of Thornthwaite equation: a case study, South of Iran. Irrigation Science, v.26 (4):303-312.

[2]. Allen, R.G., Pereira, L.S., Raes, D., Smith, M. (1998).Crop evapotranspiration. Guidelines for computing crop water requirements. FAO Irrigation and Drainage paper 56, Food and Agriculture Organization of United Nations. Rome, Italy.

[3]. Allen, R.G., Pruitt, W.O., Wright, J.L., Howell, T.A., Ventura, F., Snyder, R., Itenfisu, D., Steduto, P., Berengena, J., Yrisarry, J.B., Smith, M., Pereira, L.S., Raes, D., Perrier, A., Alves, A., Walter, I., and Elliot, R. (2006). "A recommendation on standardized surface resistance for hourly calculation of reference ET by the FAO 56 Penman Monteith method." Agricultural Water Management, 81(12): $1-22$.

[4]. Amorim, M.C. (1998). Evaluating the effectiveness of lysimeter water table constant tank Class "a" and the model penman-monteith (FAO) to reference evapotranspiration (ETo). Master's thesis. Federal University of Lust, Lust. 56 $\mathrm{p}$

[5]. ANON (1973). Guide to Umudike Agricultural Research and Training Station, Umuahia, Nigeria. Federal Agricultural Research and Training Station, Umudike Press. $40 \mathrm{pp}$.

[6]. Bernardo, S., Soares, A.A., Mantovani, E.C. (2006). Irrigation manual. 8. ed. Federal University of Vicosa, $p$ 625.

[7]. Blaney, H.F. and W.D. Criddle.(1950).Determining water requirements in irrigated areas from climatological and irrigation data. USDA/SCS, SCS-TP 96.

[8]. Blaney, H.F. and Morin, K.V. (1942). Evaporation and Consumptive Use of Water Empirical Formulas. Transaction of American Geophysical Union 50: 76-83. 
[9]. Doorenbos, J. and W.O. Pruitt. 1977. Crop water requirements. FAO Irrigation and Drainage paper 24. Food and Agriculture Organization of United Nations. Rome, Italy.

[10]. Duru, J.O. (1984). Blaney - Morin - Nigeria Evapotranspiration Model. Journal of Hydrology, 70: 7183.

[11]. FAO, 2000. Crop evapotranspiration - Guidelines for computing crop water requirements, By: R. Allen, L. Pereira, D. Raes, M. Smith, Irrigation and drainage paper 56.

[12]. Fooladmand, H.R. and Ahmadi, S.H.2009. Monthly spatial calibration of Blaney - Criddle equation for calculating monthly ETo in the South of Iran. Irrigation and Drainage, v. 58 (2): 234-245.

[13]. Gavilán, P., Lorite, I.J., Tornero, S., Berengena, J. (2006). Regional calibration of Hargreaves equation for estimating reference ET in a semiarid environment. Agriculture Water Management. Management, v. 81: 257281 .

[14]. Hargreaves, G.H. and Z.A. Samani, 1985. Reference crop evapotranspiration from temperature. Transaction of ASAE 1(2): 96-99.

[15]. Jensen, M.E. 1985. Personal communication, ASAE national conference, Chicago, IL.

[16]. Lee, K. H., \& Cho, H. Y. (2012). Simple method for estimating pan coefficient: Conversion of pan evaporation to reference evapotranspiration. Journal of irrigation and drainage engineering, 137 (1), 98-103.

[17]. Ortega-Farias, S., Irmak, S., Cuenca, R.H.(2009). Special issue on evapotranspiration measurement and modeling, Irrigation Science v. 28 (1): 1-3.

[18]. Ravazzani, G., Corbari, C., Morella, S., Gianoli, P. \&Mancini, M. (2011). Modified Hargreaves-Samani equation for the assessment reference evapotranspiration in Alphine river basin. Journal of irrigation and drainage engineering, 138 (7), 592-599.

[19]. Sediyama, G.C. 1996. Water need for crops. Brasilia: ABEAS, $176 \mathrm{p}$

[20]. Smith, M.1991 Report on the expert consultation on revision of crop water requirements. FAO, $45 \mathrm{p}$. 